\title{
Microbial aggregation and degradation of phytoplankton-derived detritus in seawater. II. Microbial metabolism
}

\author{
Bopaiah A. Biddanda* \\ Institute of Ecology, University of Georgia, Athens, Georgia 30602, USA
}

\begin{abstract}
Detritus was generated from 3 different phytoplankton sources and kept in suspension in natural seawater. Rate and efficiency of mineralization to $\mathrm{CO}_{2}$ of both dissolved and particulate fractions and conversion to microbial biomass was estimated by the 'switching substrate' technique. There was a regular process of aggregation and disaggregation of particulate organic matter associated with microbial utilization of the detritus. Approximately half the carbon in both the dissolved and particulate fractions of the detritus was processed by the microbial community in about 2 wk at $26^{\circ} \mathrm{C}$. The natural microbial community appears to be capable of utilizing both the dissolved and particulate organic carbon in the detritus equally well, when available, enabling the rapid circulation of nutrients and energy within the mixed layer. While the relative importance of the dual role of the microbial loop as a carbon mineralizer or as a carbon incorporator may vary, the cumulative effect is probably always significant in terms of control over nutrient flow to the autotrophs or carbon flow to the heterotrophs.
\end{abstract}

\section{INTRODUCTION}

The fact that bacteria can utilize a large fraction of the primary production in the sea is beginning to be widely accepted (Azam \& Ammerman 1984, Williams 1984). In marine ecosystems, a substantial fraction of photosynthetically produced organic matter may become available for heterotrophs through extracellular production, death, fragmentation and partial decomposition (Mann 1973, Field et al. 1977, Fenchel 1987). Further, the microheterotrophic community of the sea has demonstrated the potential to colonize rapidly and utilize available detritus and to undergo characteristic growth as well as succession at such resource loci (Azam \& Ammerman 1984, Biddanda \& Pomeroy 1988 [preceding article]). Goldman (1984) has further emphasized the point that was earlier made by Wangersky (1977), that nutrient regeneration in the ocean is most efficient where surfaces exist. This is because bacteria utilize only dissolved materials, and these are produced at discrete particulate loci in the marine environment. In earlier studies, it was shown,

\footnotetext{
- Present address: Alfred Wegener Institute for Polar and Marine Research, D-2850 Bremerhaven, Federal Republic of Germany
}

both in natural samples of seawater and in culture experiments, that there is a regular process of aggregation of organic matter associated with bacterial utilization of particulate substrates (Biddanda 1985, 1986).

There have also been a number of reports on the decomposition of phytoplankton (Waksman \& Carey 1935, Grill \& Richards 1964, Otsuki \& Hanya 1972, Miyoshi 1976, Cole \& Likens 1979, Newell et al. 1981, Cole et al. 1984, Newell \& Linley 1984, Fukami et al. 1985a, b), macroalgae (Waksman \& Carey 1935, Linley et al. 1981, Robinson et al. 1982), and salt marsh grass (Gosselink \& Kirby 1974, Newell et al. 1983). While these studies have provided us with valuable basic information on the processes involved, their rates and the factors that control them, there are still questions that remain unanswered.

Since most particulate matter in the sea is ultimately phytoplankton-derived, living as well as dead phytoplankton are likely to be important loci for microheterotrophic activity in the sea (Bell \& Mitchell 1972, Biddanda \& Pomeroy 1988). Such sites may constitute points of rapid microheterotrophic biomass production as well as nutrient regeneration. In this context, the events immediately following the death of episodic blooms of phytoplankton in the marine environment may be of significant importance to the carbon-energy 
economy of pelagic systems (Fenchel 1987). If we study this issue under conditions where metabolism of both the dissolved and particulate fractions of the detritus are examined at the same time at their natural concentrations, then it would perhaps give us a better description of the heterotrophic rate processes as well as an estimate of particle residence time in the water column. I therefore ask the question: What is the relative utilization of dissolved and particulate substrates in the phytoplankton detritus by the microbial community? In an attempt to answer this question, I have used detritus from 3 different phytoplankters and employed an experimental procedure that allows the simultaneous and separate measurement of utilization of both the dissolved and particulate fractions.

\section{MATERIALS AND METHODS}

Three phytoplankters from diverse taxonomic groups in axenic culture were used in the experimental investigation of this question; Synechococcus sp. (non-colonial cyanobacteria), Dunaliella sp. (autotrophic flagellate), and Cylindrotheca fusiformis (pennate diatom). A detailed experimental design was developed (Fig. 1), based on previous work by Iturriaga \& Hoppe (1977) and Ishikawa \& Nishimura (1983), which allows one to follow the fate of detritus in terms of either particulate or dissolved organic carbon while both fractions are simultaneously present.

Duplicate phytoplankton cultures were grown axenically in a clean room. One of them was labelled with ${ }^{14} \mathrm{C}$-sodium bicarbonate $\left(1 \mu \mathrm{Ci} \mathrm{ml}{ }^{-1}\right.$ of culture $)$ and equilibrated for $14 \mathrm{~d}$ to ensure uniform and optimal labeling of the photosynthates. Both cultures were freeze-heat killed $\left(-20\right.$ and $50^{\circ} \mathrm{C}$ ), the remaining dissolved inorganic carbon purged (with alternate $15 \mathrm{~min}$ bubblings with $\mathrm{CO}_{2}$ and air), and centrifuged. Then the labeled particulate organic matter was resuspended in the unlabeled dissolved organic matter collected as $0.45 \mu \mathrm{m}$ filtrate, and the unlabeled particulate organic matter was resuspended in the labeled, $0.45 \mu \mathrm{m}$ filtered dissolved organic matter. Subsamples of $1 \mathrm{ml}$ of each were added to $10 \mathrm{ml}$ unfiltered seawater taken in acid-cleaned $20 \mathrm{ml}$ glass scintillation vials giving parallel sets. Surface seawater was collected from a mid-shelf region off Georgia, USA. The final concentration of organic matter was approximately $10 \mathrm{mg}^{-1}$ (about $6 \mathrm{mg} \mathrm{POC} \mathrm{l}^{-1}$, with a specific activity of $5000 \mathrm{dpm} \mathrm{ugC}^{-1}$; and about $4 \mathrm{mg} \mathrm{DOC} \mathrm{l}^{-1}$, with a specific activity of $5000 \mathrm{dpm} \mu \mathrm{gC}^{-1}$ ), which is comparable to that found under natural conditions during phytoplankton blooms (Newell et al. 1981, Fukami et al. 1985a, b)

The microcosms were then incubated in the dark at

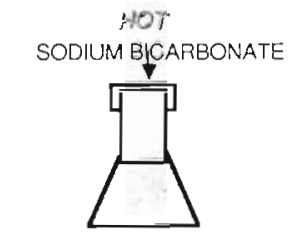

Phytoplankton culture

flask

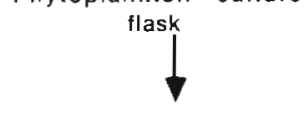

Centrifuge at $20000 \mathrm{rpm}$

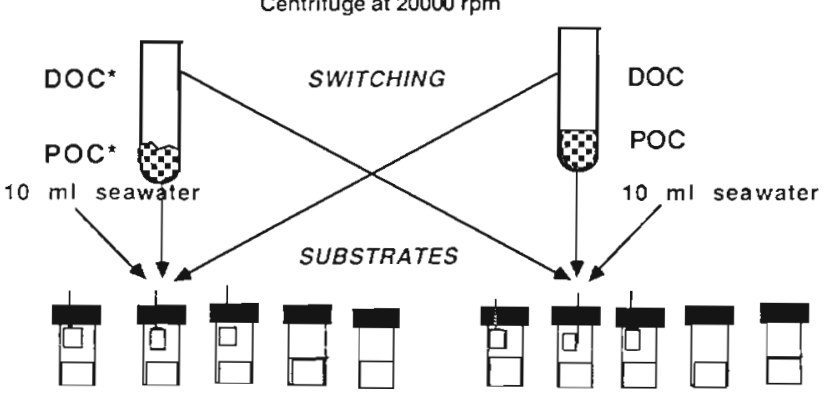

$\mathrm{POC}^{\star}+\mathrm{DOC}$

$\mathrm{POC}+\mathrm{DOC}^{*}$

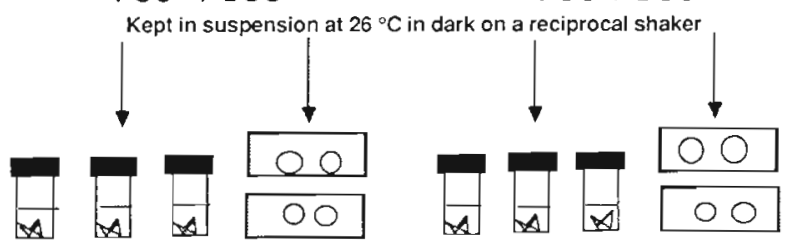

$\mathrm{CO}_{2}$ wicks in scint. fluid.

Slides for microbes

Fig. 1. Schematic flow chart of the substrate switching technique. 'Indicates the radiolabeled fraction

$26^{\circ} \mathrm{C}$ and gently shaken on a reciprokal shaker. At various intervals, triplicate microcosms were recovered to determine mineralization of substrates by trapping the ${ }^{14} \mathrm{CO}_{2}$ evolved onto wicks wetted with $0.2 \mathrm{ml}$ betaphenethylamine, following acidification of the seawater with $0.2 \mathrm{ml} 5 \mathrm{~N} \mathrm{H}_{2} \mathrm{SO}_{4}$. Additional duplicate microcosms were used to prepare slides for the enumeration of microorganisms by the acridine-orange directcount technique following preservation of the sample in Lugol's Iodine (Nishino 1986). In addition to following the label in both the particulate and dissolved fractions, changes in particulate organic carbon were measured using a Perkin-Elmer Model 200 carbon, hydrogen, nitrogen analyzer, and changes in dissolved organic carbon were measured by means of a Oceanography International Model 700 Total Organic Carbon analyzer. Microcosms recovered at zero hour constituted the controls. To estimate bacterial carbon, I employed here the bacteria cell to carbon conversion factor of $20 \mathrm{fg}$ (bacteria cell) ${ }^{-1}$ (Fuhrman \& Azam 1980 Jacobsen \& Azam 1984). I estimated the carbon conversion efficiency $\left(\mathrm{C}_{e}\right)$, which is an expression for the yield of net bacterial carbon produced per unit carbon 
utilized from the detritus (Linley 1983, Linley \& Newell 1984), according to the formula:

$$
\mathrm{C}_{\mathrm{e}}=\frac{\text { Carbon incorporated into bacteria }}{\text { Carbon utilized from the detritus }} \times 100
$$

The advantages of the switching substrate technique are that it (1) minimizes the rapid initial leaching from fresh detritus, (2) eliminates the artifacts due to the presence of filters along with the substrate in the microcosm, (3) is more realistic in having all the components of the natural environment, and (4) allows the investigator to follow the fate of detritus in terms of either particulate or dissolved organic carbon while both fractions are simultaneously present, in terms of carbon respired and carbon incorporated into microbial biomass.

\section{RESULTS}

With Synechococcus sp. and Dunaliella sp. detritus, there were no significant differences (alpha $=0.0001$ ) in the rate of mineralization of particulate and dissolved organic matter, as is evident from the logarithmic best fit curves drawn (Fig. 2). In the case of both Synechococcus and Dunaliella, just one curve served to describe the behavior of both particulate and dissolved organic carbon, whereas in the case of Cylindrotheca fusiformis dissolved organic matter was mineralized somewhat faster than particulate matter (Fig. 2). In all cases, however, there was an initial rapid rate of detritus utilization which slowed as time progressed, and by Day 16 , between 32 and $63 \%$ of the initial detritus (in terms of both dissolved and particulate organic carbon fractions) had been respired. Also by this time, about 3 to $4 \%$ of the detritus carbon had been incorporated into bacterial biomass (Table 1). This meant that between 36 and $67 \%$ of the detritus was utilized (carbon respired + carbon incorporated into bacterial biomass) by the end of $16 \mathrm{~d}$ (Table 2). The highest rates of detritus utilization (13.6 to $19.5 \%$, which is the amount incorporated into biomass plus the amount respired) occurred during the 1 st day, remaining high during the 2 nd day (9.5 to $10.2 \%$, and decreasing steadily thereafter. We can expect these numbers to be somewhat higher if we consider the production of bacterivorous protozoa in this detritus-based system. On the average, however, about half of the carbon (both particulate and dissolved) present in the original detritus had been utilized by the microbial community in $2 \mathrm{wk}$ at $26^{\circ} \mathrm{C}$ in seawater, with approximately $25 \%$ having been utilized by the end of the first $2 \mathrm{~d}$.

The highest $C_{e}$ values (Table 3 ), which were recorded at the end of Day 1, were $23.8 \%$ for Synechococcus sp., $29.9 \%$ for Dunaliella sp., and 32.9 and
$28.3 \%$ (average: $30.6 \%$ ) for Cylindrotheca fusiformis particulate and dissolved fractions, respectively. The average daily $\mathrm{C}_{\mathrm{e}}$ for the $16 \mathrm{~d}$ duration was $10.6 \%$ for Synechococcus, $15.8 \%$ for Dunaliella, and 19.1 and $21.9 \%$ (average: $20.5 \%$ ) for C. fusiformis particulate and dissolved fractions, respectively.
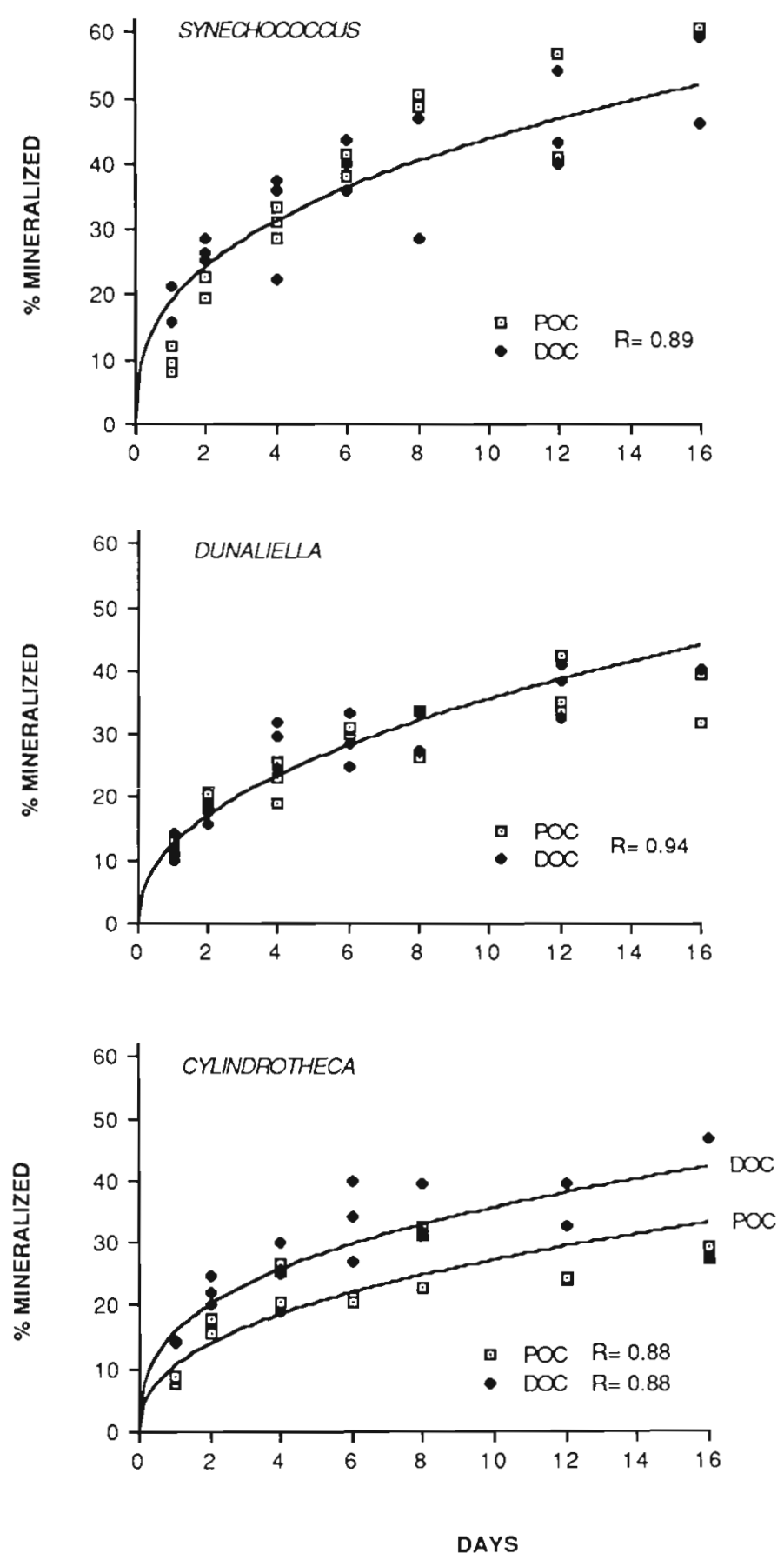

Fig. 2. Mineralization of Synechococcus sp., Dunaliella sp., and $C y$ lindrotheca fusiformis detritus in seawater as percentage of total $\mathrm{PO}^{14} \mathrm{C}$ and $\mathrm{DO}^{14} \mathrm{C}$ respired to ${ }^{14} \mathrm{CO}_{2}$ 
Table 1 Bacterial carbon (...g $\left.\left.\right|^{-1}\right)$ associated with degrading phytoplankters in seawater Numbers in parentheses: $\%$ of total detritus carbon incorporated into bacterial biomass

\begin{tabular}{|rrrrrrr}
\hline Day & & Cumulative & & & \multicolumn{1}{c|}{ Daily } \\
Dunaliella & Cylindrotheca \\
\hline 1 & $206(2.06)$ & $247(2.47)$ & $206(2.06)$ & $206(2.06)$ & $247(2.47)$ & $206(2.06)$ \\
2 & $246(2.46)$ & $276(2.76)$ & $285(2.85)$ & $40(0.40)$ & $29(0.29)$ & $79(0.79)$ \\
4 & $281(2.81)$ & $328(3.28)$ & $323(3.23)$ & $17(0.17)$ & $26(0.26)$ & $19(0.19)$ \\
8 & $315(3.15)$ & $359(3.59)$ & $365(3.65)$ & $8(0.08)$ & $7(0.07)$ & $21(0.21)$ \\
16 & $340(3.40)$ & $390(3.90)$ & $389(3.89)$ & $3(0.03)$ & $4(0.04)$ & $4(0.04)$ \\
\hline
\end{tabular}

Table 2. Phytoplankton-detrital carbon utilized ( $\left.\mu \mathrm{g} \mathrm{Cl}^{-1}\right)$ in seawater. Numbers in parentheses: \% of detrital particulate carbon or detrital dissolved carbon utilized

\begin{tabular}{|c|c|c|c|c|c|c|}
\hline \multirow[t]{2}{*}{ Day } & \multicolumn{3}{|c|}{ Cumulative } & \multicolumn{3}{|c|}{ Daily } \\
\hline & Synechococcus & Dunaliella & Cylindrotheca & Synechococcus & Dunaliella & Cylindrotheca \\
\hline \multicolumn{7}{|l|}{ POC } \\
\hline 1 & $806(13.43)$ & $1027(17.11)$ & $626(10.43)$ & $806(13.43)$ & $1027(17.11)$ & $626(10.43)$ \\
\hline 2 & $1566(26.10)$ & $1476(24.60)$ & $1245(20.75)$ & $760(12.66)$ & $449(7.48)$ & $619(10.31)$ \\
\hline 4 & $2141(35.68)$ & $1828(30.46)$ & $1703(28.38)$ & $287(4.83)$ & $176(2.93)$ & $229(3.81)$ \\
\hline 8 & $3340(55.66)$ & $2159(35.98)$ & $1985(33.08)$ & $299(4.98)$ & $82(1.36)$ & $70(1.16)$ \\
\hline 16 & $4060(67.66)$ & $2490(41.50)$ & $2187(36.45)$ & $90(1.50)$ & $41(0.68)$ & $25(0.41)$ \\
\hline \multicolumn{7}{|l|}{ DOC } \\
\hline 1 & $926(23.15)$ & $687(17.17)$ & $726(18.15)$ & $926(23.15)$ & $687(17.17)$ & $726(18.15)$ \\
\hline 2 & $1326(33.15)$ & $996(24.90)$ & $1165(29.12)$ & $400(10.00)$ & $309(7.72)$ & $439(10.97)$ \\
\hline 4 & $1601(40.02)$ & $1528(38.20)$ & $1323(33.07)$ & $137(3.42)$ & $266(6.65)$ & $79(1.97)$ \\
\hline 8 & $1835(45.87)$ & $1639(40.97)$ & $1685(42.12)$ & $58(1.45)$ & $27(0.67)$ & $90(2.25)$ \\
\hline 16 & $2420(60.50)$ & $1910(47.72)$ & $1829(45.72)$ & $73(1.83)$ & $33(0.82)$ & $18(0.45)$ \\
\hline
\end{tabular}

Table 3. Bacterial carbon conversion efficiencies $\left(\mathrm{C}_{\mathrm{e}}\right)$ for phytoplankton-detritus in seawater

\begin{tabular}{|c|c|c|c|c|c|c|c|c|c|c|c|c|}
\hline \multirow[t]{3}{*}{ Day } & \multicolumn{6}{|c|}{ Particulate Organic Matter } & \multicolumn{6}{|c|}{ Dissolved Organic Matter } \\
\hline & \multicolumn{2}{|c|}{ Synechococcus } & \multicolumn{2}{|c|}{ Dunaliella } & \multicolumn{2}{|c|}{ Cylindrotheca } & \multicolumn{2}{|c|}{ Synechococcus } & \multicolumn{2}{|c|}{ Dunaliella } & \multicolumn{2}{|c|}{ Cylindrotheca } \\
\hline & Cumulative & Daily & Cumulative & Daily & Cumulative & Daily & Cumulative & Daily & Cumulative & Daily & Cumulative & Daily \\
\hline 1 & 25.5 & 25.5 & 24.0 & 24.0 & 32.9 & 32.9 & 22.2 & 22.2 & 35.9 & 35.9 & 28.3 & 28.3 \\
\hline 2 & 15.7 & 5.2 & 18.7 & 6.4 & 22.9 & 12.7 & 18.5 & 10.0 & 27.7 & 9.9 & 24.4 & 18.0 \\
\hline 4 & 13.1 & 6.1 & 17.9 & 14.7 & 18.9 & 8.3 & 17.5 & 12.7 & 21.4 & 9.7 & 24.4 & 24.0 \\
\hline 8 & 9.4 & 2.8 & 16.6 & 9.3 & 18.0 & 30.0 & 17.1 & 14.6 & 21.9 & 28.5 & 21.2 & 16.6 \\
\hline 16 & 8.3 & 3.4 & 15.6 & 9.4 & 17.7 & 12.0 & 14.0 & 4.2 & 20.4 & 11.7 & 21.2 & 16.6 \\
\hline Aver & & 8.6 & & 12.7 & & 19.1 & & 12.7 & & 19.0 & & 21.9 \\
\hline
\end{tabular}

\section{DISCUSSION}

\section{Microbial utilization of detrital carbon}

I have found a similar pattern of utilization of both particulate and dissolved organic carbon from all 3 phytoplankters. The only difference, and it was a relatively minor one, was in the case of Cylindrotheca fusiformis, where the dissolved fraction was mineralized somewhat faster than the particulate fraction. Probably, this is due to the resistance of the frustule of the diatom and its effect on the ability of bacteria to penetrate and utilize the contents. It appears that the frustules of the diatom may delay the utilization of particulate carbon, but once bacteria or their enzymes penetrate the frustule, it is mineralized. Gunnison \& 
Alexander (1975), and Fukami et al. (1985a), have made reference to the relative resistance to biodegradation of specific components of algal cell walls, especially those of silicious diatoms.

The $C_{e}$ for detritus of the 3 phytoplankton species varied between 8.6 and $21.9 \%$ (average: 10.6 to $20.5 \%$ ), and is within the range for phytoplankton detritus recorded by other workers (Newell et al. 1981, Linley 1983, Fukami et al. 1985a, b) for phytoplankton. The $C_{e}$ budget for the whole phytoplankton detritus suggests that about 30 to $35 \%$ of the carbon in the detritus is mineralized ( 34 to $39 \%$ is utilized) by the microbial community in $4 \mathrm{~d}$, whereas up to $63 \%$ is mineralized within $16 \mathrm{~d}$. It is apparent from this that the rapid rates of utilization of detritus recorded in the first $4 \mathrm{~d}$ coincide with the period of detritus aggregation that is mediated by microbial activity (Biddanda \& Pomeroy 1988). This aggregated state therefore seems to correspond to the period of rapid detritus utilization. The rate of utilization decreases steadily thereafter as the more refractory compounds in the particulate and dissolved pools (inferred from the decreasing trend in daily $C_{e}$ for all 3 carbon sources) are gradually mineralized or incorporated by the microbial community. Observations also indicate that the early ( 1 to $4 \mathrm{~d}$ ) microbial community with bacteria that are mostly rods and cocci is similar to those found during the initial phases of degrading blooms of phytoplankton, while the low-density and high-diversity community that appeared 8 to $16 \mathrm{~d}$ later with a variety of bacteria and protozoa is characteristic of those found during the terminal phases of such episodic events (Hoppe 1981, Fenchel 1987, Biddanda \& Pomeroy 1988).

It appears that approximately one quarter and one half of the carbon in the newly introduced detritus may be utilized by the microbial community in $2 \mathrm{~d}$ and in $16 \mathrm{~d}$, respectively. While this may be the case for most phytoplankton, studies of freshwater and estuarine higher plants (Benner et al. 1984a, b), which contain lignocellulose, suggest that utilization of some of these compounds may be slower than is the utilization of phytoplankton.

The natural microbial community appears therefore to be capable of utilizing both particulate and dissolved organic carbon in phytoplankton detritus equally well when both are available. So perhaps the resource environment of the heterotrophic bacteria cannot be fully described by us only in terms of the amounts of particulate and dissolved organic carbon present. It would seem that in nature, the microbial assemblage encounters detritus as a milieu of substrates, rather than as the inputs of pure, individual substances, and in response has developed the potential, through functional and taxonomic diversity within the community, to utilize detritus as a whole. Hence, it does not appear to matter whether organic matter is in a dissolved or particulate state - what appears to matter, however, is accessibility of the resource and susceptibility to biodegradation by the exoenzymes of the microorganisms.

\section{Detrital carbon flow in the pelagic food web}

In studies of bacterial utilization of organic matter, a distinction is usually made between particulate and dissolved organic matter. Although convenient, this distinction is too simplistic and unrealistic (Azam \& Ammerman 1984). We have seen that the natural microbial community can utilize both dissolved and particulate materials rapidly. Heterotrophic bacteria, however, can actually utilize only dissolved organic compounds, and therefore must colonize particles and convert them to dissolved substances prior to assimilation. Since bacteria do not directly utilize either particulate organic matter or even dissolved polymers, but must obtain their resource (utilizable dissolved organic matter) from discrete particulate loci where the resources are concentrated, we may do better to begin to describe the environment of the microbe in terms of utilizable dissolved organic matter regime, as suggested earlier by Azam \& Ammerman (1984). The detritosphere concept (Biddanda \& Pomeroy 1988) would provide a suitable context for beginning such considerations in the vicinity of degrading detritus in the sea. It follows therefore, that it is impractical to strictly differentiate between particle-attached and free-living microbes before we can determine what proportion is particleassociated.

In the oceanic plankton, episodic events such as the collapse of phytoplankton blooms and formation of animal feces present sudden and large available resources to the microheterotrophic community and to larger animals as well. The rate at which the microbes will utilize this resource and the rates at which these particles will sink out of the system will determine their trophic value to the rest of the heterotrophs in the mixed layer. If we assume an average particle residence time of approximately $30 \mathrm{~d}$ in the mixed layer (Lande \& Wood 1987), the results of this study indicate that there is ample opportunity for a rapid recycling of the detritus-bound carbon within the mixed layer. Since 25,32 , and $63 \%$ of the organic matter in the detritus is mineralized by 2,4 , and $16 \mathrm{~d}$, respectively, and very little (about $2 \%$ ) is found incorporated in microorganism biomass at any time, the microbial community itself may be of minor importance as a carbon resource for metazoans. On the other hand, the aggregated detritus-microbe complex occurring between 1 and $4 \mathrm{~d}$ may constitute a significant carbon resource to 


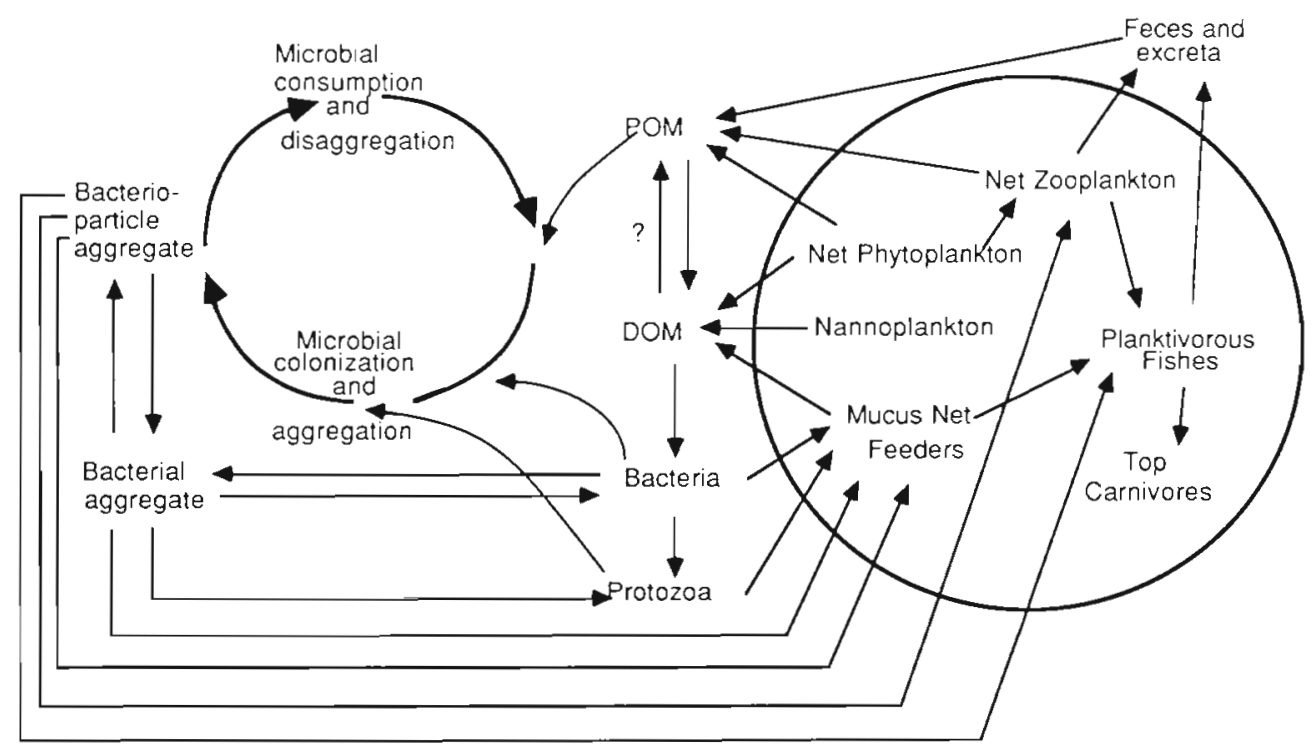

Fig. 3. Schematic diagram of pathways for energy flow in the ocean's food web

metazoans that are capable of consuming them (Biddanda 1985). This is also the period when the maximum daily production of bacteria (about $250 \mu \mathrm{g}$ $\mathrm{Cl}^{-1}$ ) is associated with the aggregates, and the metazoans may consume significant amounts of bacterial carbon.

In Fig. 3, I present a conceptual model for the flow of energy in the ocean's food web. Though it is only a modification of the earlier model (Pomeroy 1974), aspects of particle behavior mediated through microbial activity are included identifying the several alternatives available within such a system for the microbial component to serve both as a remineralizing unit and as a carbon incorporator within the mixed layer. The function of the microbial loop as a carbon sink or a carbon link to metazoa should be considered in the overall context and not solely in the context of food webs that are force-directed towards fishes. Evidently there are other purposes involved in the maintenance of complex food webs in nature, other than the support of terminal consumers.

Acknowledgements. This work was supported through a research grant from the U.S. Department of Energy (DEFG09-86ER60451) to Dr Lawrence Pomeroy. Hugh Ducklow, Farooq Azam. Bill Wiebe, Stuart Findlay, Dan Perlmutter, Ron Benner, Sam Wainwright, Don Douglas and Larry Pomeroy gave constructive feedback on the experimental design while it was being developed. Larry Pomeroy, Bill Wiebe, Bob Hodson, Karen Porter, Eugene Odum and Peter Griffith read and commented on the manuscript. Bob Sanders helped with growing phytoplankton cultures. Patty Freeman-Lynde taught me how to use the Macintosh and helped with the figures. Comments by 3 anonymous reviewers helped to improve this paper considerably. I acknowledge all this support and encouragement with gratitude.

\section{LITERATURE CITED}

Azam, F., Ammerman, J. W. (1984). Cycling of organic matter by bacterioplankton in pelagic marine ecosystems: microenvironmental considerations. In: Fasham, M. J. R. (ed.) Flows of energy and materials in marine ecosystems. Plenum Press, New York, p. 345-360

Bell, W., Mitchell, R. (1972). Chemotactic and growth responses of marine bacteria to algal extracellular products. Biol. Bull. mar. biol. Lab., Woods Hole 143: 265-277

Benner, R., Maccubbin, A. E., Hodson, R. E. (1984). Preparation, characterization, and microbial degradation of specifically radiolabeled $\left({ }^{14} \mathrm{C}\right)$ Lignocellulose from marine and freshwater macrophytes. Appl. environ. Microbiol. 47 (2): 381-389

Benner, R., Newell, S. Y., Maccubbin, A. E., Hodson, R. E. (1984). Relative contributions of bacteria and fungi to rates of degradation of lignocellulosic detritus in salt-marsh sediments. Appl environ. Microbiol. 48 (1): 36-40

Biddanda, B. A. (1985). Microbial synthesis of macroparticulate matter. Mar. Ecol. Prog. Ser. 20: 241-251

Biddanda, B. A. (1986). Structure and function of marine microbial aggregates. Oceanol. Acta 9 (2): 209-211

Biddanda, B. A., Pomeroy, L. R. (1988). Microbial aggregation and degradation of phytoplankton-derived detritus in seawater. I. Microbial succession. Mar. Ecol. Prog. Ser. 42; $79-88$

Cole, J. J., Likens, G. E. (1979). Measurements of mineralization of phytoplankton detritus in an oligotrophic lake. Limnol. Oceanogr 24: 541-547

Cole, J. J., Likens. G. E., Hobbie, J. E. (1984). Decomposition of planktonic algae in an oligotrophic lake. Oikos 42 : $257-266$

Fenchel, T (1987). Ecology of protozoa: the biology of freeliving phagotrophic protists. Brock/Springer Series, Contemporary Broscience. Springer-Verlag, New York, p. $86-151$

Field, J. G., Jarman, N. G., Dieckmann, G. S., Griffiths, C. L., Velimirov, B., Zoutendyk, P. (1977). Sun, waves, seaweed and lobsters: the dynamics of a west-coast kelp bed. S. Afr J. Sci. $73: 7-10$ 
Fuhrman, J. A., Azam, F. (1980). Bacterioplankton secondary production estimates for coastal waters of British Columbia, Antarctica, and California. Appl environ. Microbiol 39: 1085-1095

Fukami, K., Simidu, U., Taga, N. (1985a). Microbial decomposition of phyto- and zooplankton in sea water. 1. Changes in organic matter. Mar. Ecol. Prog. Ser $21 \quad 1-5$

Fukami, K., Simidu, U., Taga, N. (1985b). Microbial decomposition of phyto- and zooplankton in sea water 2. Changes in the bacterial community. Mar Ecol. Prog Ser 21: $7-13$

Goldman, J. C. (1984). Oceanic nutrient cycles. In: Fasham, M. $J$. (ed.) Flow of energy and materials in marine ecosystems: theory and practice. Plenum Press, New York, p. 137-170

Gosselink, J. G., Kirby, C. J. K. (1974). Decomposition of salt marsh grass, Spartina alterniflora Loisel. Limnol. Oceanogr. 19 (5): 825-832

Grill, E. V., Richards: F. A. (1964). Nutrient regeneration from phytoplankton decomposing in sea water. J. mar. Res. 22 $51-69$

Gunnison, D., Alexander, M. (1975). Resistance and susceptibility of algae to decomposition by natural microbial communities. Limnol. Oceanogr. 20 (1): $64-70$

Hoppe, H.-G. (1981). Blue-green algae agglomeration in surface water: a microbiotope of high bacterial activity. Kieler Meeresforsch. (Sonderh.) 5: 291-303

Ishikawa, M., Nishimura, H. (1983). A new method of evaluating the mineralization of particulate and dissolved photoassimilated organic matter J. oceanogr Soc. Japan 39 $29-42$

Iturriaga, R., Hoppe, H.-G. (1977). Observations of heterotrophic activity on photoassimilated organic matter Mar. Biol. 40: 101-108

Jacobsen, T R., Azam, F. (1984). Role of bacteria in copepod fecal pellet decomposition: colonization, growth rates and mineralization. Bull. mar. Sci. 35 (3): 495-502

Lande, R., Wood, A. M. (1987). Suspension times of particles in the upper ocean. Deep Sea Res. 34 (1): 61-72

Linley, E. A. S. (1983). The role of microorganisms in the decomposition of plant detritus in the sea. Ph.D. thesis, University of Exeter, U.K.

Linley, E. A. S., Newell, R. C. (1984). Estimates of bacterial growth yields based on plant detritus. Bull. mar. Sci. 35 (3): $409-425$
Linley, E. A. S., Newell, R. C., Bosma, S. A. (1981). Heterotrophic utilization of mucilage released during fragmentation of kelp (Ecklonia maxima and Laminaria pallida) 1. Development of microbial communities associated with the degradation of kelp mucilage. Mar. Ecol. Prog. Ser. 4: $31-41$

Mann, K. H. (1973). Seaweeds: their productivity and strategy for growth. Science 182: 975-981

Miyoshi, H. (1976). Decomposition of marine plankton under laboratory conditions. Bull. Jap. Soc. scient. Fish. 42 1205-1211

Newell, R. C., Linley, E. A. S. (1984). Significance of microorganisms in the decomposition of phytoplankton: estimates of carbon and nitrogen flow based on the biomass of plankton communities. Mar Ecol. Prog. Ser 16: 105-119

Newell, R. C., Lucas, M. I., Linley, E. A. S. (1981). Rate of degradation and efficiency of conversion of phytoplankton debris by marine microorganisms. Mar Ecol. Prog. Ser. 6 123-136

Newell, R. C., Linley, E. A. S., Lucas, M. I. (1983). Bacterial production and carbon conversion based on salt marsh plant debris. Estuar. coast. Shelf Sci. 17: 405-419

Nishino, S. (1986). Direct acridine orange counting of bacteria preserved with acidified Lugol's iodide. Appl. environ Microbiol. 52 (3): 602-604

Otsuki, A., Hanya, T (1972). Production of dissolved organic matter from dead green algal cells. 1. Aerobic microbial decomposition. Limnol. Oceanogr 17 (2): 248-257

Pomeroy, L. R. (1974). The ocean's food web, a changing paradigm. BioScience 24: 499-504

Robinson, J. D., Mann, K. H., Novitsky, J. A. (1982). Conversion of the particulate fraction of seaweed detritus to bacterial biomass. Limnol. Oceanogr. 27 (6): 1072-1079

Waksman, S. A., Carey, C. L. (1935). Decomposition of organic matter in sea water by bacteria. 2. Influence of addition of organic substances upon bacteria activities. J. Bacteriol. 29-30 (5): 545-562

Wangersky, P. J. (1977). The role of particulate matter in the productivity of surface water. Helgoländer wiss. Meeresunters. 30: 546-564

Williams, P. J. LeB. (1984). Bacterial production in the marine food chain: the emperor's new suit of clothes? In: Fasham M. J. R. (ed.) Flows of energy and materials in marine ecosystems. Plenum Press, New York, p. 271-299 